\title{
Liquidity buffers determinants in GCC's Islamic banks
}

\author{
Amal Essayem ${ }^{1}$, Wided Khiari ${ }^{1}$ and Azhaar Lajmi ${ }^{1}$
}

\begin{abstract}
The purpose of this paper is to understand determinants of liquidity buffers in the GCC's Islamic banks. We apply the model of Bonner et al. (2005) on balanced panel data, bank specific data and annual balance sheet data for all reporting banks. The data cover a period of 8 years from 2004 until 2011 for 24 Islamic banks from GCC region that includes mainly Saudi Arabia, United Arab Emirates, Bahrain and Kuwait. Results show that liquidity buffers negatively related to the size of the bank, the capitalization is negatively related to liquidity buffers in Islamic banks in the GCC region and the ratio of deposits is negatively related to liquid assets holding in Islamic banks, but not statistically significant. In addition, we found a positive relationship between the profitability and liquidity buffers in Islamic banks of the GCC region. Finally, we found a different result when it comes to macroeconomic variables. First we noticed a negative impact of the inflation on liquidity buffers and second, a positive significant relationship between GDP real growth and liquidity buffers in Islamic banks in the GCC region. Our findings can serve as a tool for policy makers in the GCC region to adopt sounder strategies of liquidity management.
\end{abstract}

JEL classification numbers: $\mathrm{G} 2, \mathrm{C} 1$

Keywords: Islamic banking, GCC region, Liquidity Buffers, panel regression.

\section{Introduction}

Banks create liquidity on the base of their balance sheets by the process of transforming liquid liabilities to illiquid assets (which is known as the productive loans) and according to the intermediation theory this transformation is in the core of the fulfillment of the bank's role in the economy which is creating liquidity and transferring risks to boost the economic growth. Hence, liquidity is the cornerstone of the banking industry. Unfortunately, there is a wide agreement that insufficient liquidity buffers were an essential cause of the 2008 financial crisis and the ongoing shortcomings of the international financial system. This complication makes the enhancement of liquidity analysis and supervision a key issue for the coming years. However, liquidity creation is not allowed in Islamic banking as it generates interest, hence Islamic banks keep loads of liquid assets considering the lack of financial instruments. Therefore, Islamic banks gained the reputation of highly safe banks thanks to their large liquidity buffers. Nonetheless, it is important to understand the determinants of this liquidity.

The objective of this paper is to provide a comprehensive picture on this issue, by reviewing existing literature and empirical findings, and by providing some tests of theoretical predictions, using Islamic banking data in the GCC countries. To the best of our knowledge, this article is the first attempt to understand the determinants of liquidity buffers in GCC region's Islamic banks.

\footnotetext{
${ }^{1}$ Institut Supérieur de Gestion, GEF-2A Laboratory, 2000, Le Bardo, University of Tunis, Tunisia.
}

Article Info: Received: August 7, $2020 \quad$ Published online: September 15, 2020 
Indeed, Vogel and Hayes (1998) emphasize that liquidity is one of the main problems causing the slow growth of Islamic banking. Abdul rahman (1999) and How et al. (2004) states that Islamic banks have to provide self-insurance by keeping their reserve requirements around 100\%. Also Hassan and Dridi (2010) mention the same conclusion which is Islamic banks are highly liquid because of self-insuring motives. Cihak and Hesse (2010) reported that Islamic banks may face risk management challenges specifically when it comes to liquidity risk management with the growth of its size (the bank size). Hence, these financial institutions need a more strict mechanism to asses and monitor risk management (Ismal, 2008, 2010). These complications are related to the fact that Islamic banking started exposing to a more complex business environment, for instance lack of accurate regulation an increase in competition, besides the challenging idiosyncratic characteristics specific to the structure of Islamic banks( Iqbal and Mirakhor,2007).

In addition, Iqbal and Mirakhor (2007) stated that the business model of Islamic banks are in constant change due to many factors like; competition, financial innovation, changing in economy, and transformation in the banking sector which may cause an erratic behavior of liquidity in Islamic banks. Following the same logic, Ali (2013) states that liquidity state in Islamic banks have been changing toward a lower level of liquid assets and an increasing maturity gap in the short term assets and liabilities, which may increase liquidity risk without having the right tools and regulation to tackle it. Hence, the situation calls to revise liquidity management products and policy. Not only that, also there is an urgent need to understand the source of variation of the liquidity, we have to identify these determinants so banks can prevent erratic levels of liquidity even in the absence of tools and efficient mechanism. This is about developing a preventive policy by understanding than controlling variables that determines the liquidity position.

The remainder of this paper is structured as follows: section 1 describes methodology's framework. In section 2 we analyze the main results. Finally, section 3 includes the concluding remarks.

\section{Literature review}

Bonner et al. (2015) studied 7000 financial institutions including banks in 30 OECD countries from 1998 to 2011. They used bank specific contextual factors to explain the liquid assets holding. They found that their set of variables has economically and statistically a significant impact on banks liquidity holdings. They found a negative relationship between liquidity holdings and business model, which is a proxy that express the level of risk exposure. They also found a positive relationship between deposit and liquidity buffer, it can be explained by a lack of funding diversification as deposits are considered the most stable source of financing. They also found a positive relationship between profit and liquidity holdings. However, the capital ratio had no significant impact on liquid assets holding of the banks in their sample. Disclosure has a positive relationship with liquidity buffers and concentration has a negative impact on it. $\mathrm{He}$ also found a negative nonlinear relationship of size and liquidity holdings. Finally, he concluded that most factors can be replaced by regulation of liquidity except the disclosure that only is to compliment the liquidity regulation added to the size.

Aspachs et al. (2005) studied the determinants of bank liquidity buffers using a sample of 57 UK owned and foreign banks over the period from 1985 to 2003 . They measured liquidity buffers using two liquidity ratio, the first is liquid assets over total assets and the second is liquid assets over deposits. Basically, they found the same results using both liquidity ratio. They found a negative impact of the lender of last resort on liquidity holdings. It shows that higher the probability to bailout, the less banks hold liquid assets, because they do not have an incentive to self-insurance motive. They found a negative impact of the interest rate on liquidity holdings. It indicates that when authorities decide to boost the economy by reducing the interest rate, liquidity buffers will decrease. They found, also, a negative relationship between the GDP real growth and liquidity holdings, which means that banks tend to hold less liquid 
assets in period of economic growth, most likely is because of the low level of risk, so banks have fewer incentives to be self-insured.

Délechat et al. (2012) studied the determinants of liquidity buffers in CAPDR countries using a panel data of 100 commercial banks from 2006-2010. They found a negative impact of the capital ratio, meaning highly capitalized banks are less liquid. They found a negative impact of the net interest income on liquidity buffers, meaning that profitability impact negatively the liquidity. They also found a negative impact of the size on liquidity which is in line with theoretical prediction stated in the "too big to fail" theory. Foreign owned banks had a negative relationship with liquidity buffers, meaning that they are not financially constrained. In fact, they can benefit from the diversification of their funding sources coming from abroad. They found a negative relationship between liquidity buffer and interest rate. Besides, they found the same results for deposit volatility, inflation, presence of the lender of last resort, and the net international reserves. Finally, they found a positive impact of deposit dollarization and liquidity buffer; this may not imply a direct causality link, contradictory this may reflect the low quality of the domestic financial institution.

Ahmad et al. (2013) studied the determinants of Islamic banks liquidity in the Malaysian context using a sample of 17 Islamic banks during the period of 15 years from 1994 to 2009 . They used a transformation ratio - total deposits over total assets- to detect the level of liquidity in the Islamic banks of Malaysia. They used a set of both idiosyncratic and macroeconomic variables. They used total financing, profitability, size, capital requirement, short-term interest rate, money supply, inflation rate, and real growth gross domestic product. They found a very volatile liquidity ratio; it had a stander deviation of about 22.47 indicating that Islamic banks are not really excessively liquid because they use the liquidity they have. They found a positive relationship between total financing and liquidity. However, they did not find any significant impact of capitalization on liquidity. Finally, they found a negative relationship between liquidity and macroeconomic variables.

Based on analogy, we will use these studies to identify the liquidity buffers in Islamic banks in the Gulf countries.

\section{Methods and materials}

In this section, we will try to test a model and a set of tests to compare our findings to the literature. We aim to test empirically the determinants of liquidity buffers in Islamic banking institutions.

\section{1. The data: sources and variables construction}

In this section, we use balanced panel data, bank specific and annual balance sheet data for all reporting banks from bureau van Dijk's bankscope database for the period from 2004 until 2011 for 24 Islamic banks from GCC region that includes mainly Saudi Arabia, United Arab Emirates, Bahrain and Kuwait. Also by choosing countries mentioned below, we reduce the risk of unobserved underlying heterogeneity in domestic banking system; it means we tried to have only countries that have a dual banking system.

We only retain banks for which we can at least obtain 4 bank-year observations, guaranteeing sufficient intra-institutional variation.

Our dependent variable, capturing liquidity holdings, is liquid asset devised by deposits and short term funding. This ratio enable as to capture better the bank's vulnerability toward specific kind of funding essentially: deposits of households, enterprises, banks and other financial institution, and funds from debt securities issued by the bank. (Shahchera, 2012; Délechat, 2012; Aspachs et al., 2005).

Additional control variables, capturing macroeconomic conditions as well as domestic financial development, are obtained from the World Bank data base. 


\subsection{Descriptive statistics}

Descriptive statistics were conducted to observe the statistical properties of the data used as variables, for instance the mean, standard deviation and normality of the data. Table 1 shows the summary statistics of the dependent variable liquidity assets. The statistical characteristics of the dependent variable the liquidity buffer are also given by Table 1 below.

Table 1: Summary statistics of the dependent variable Y1

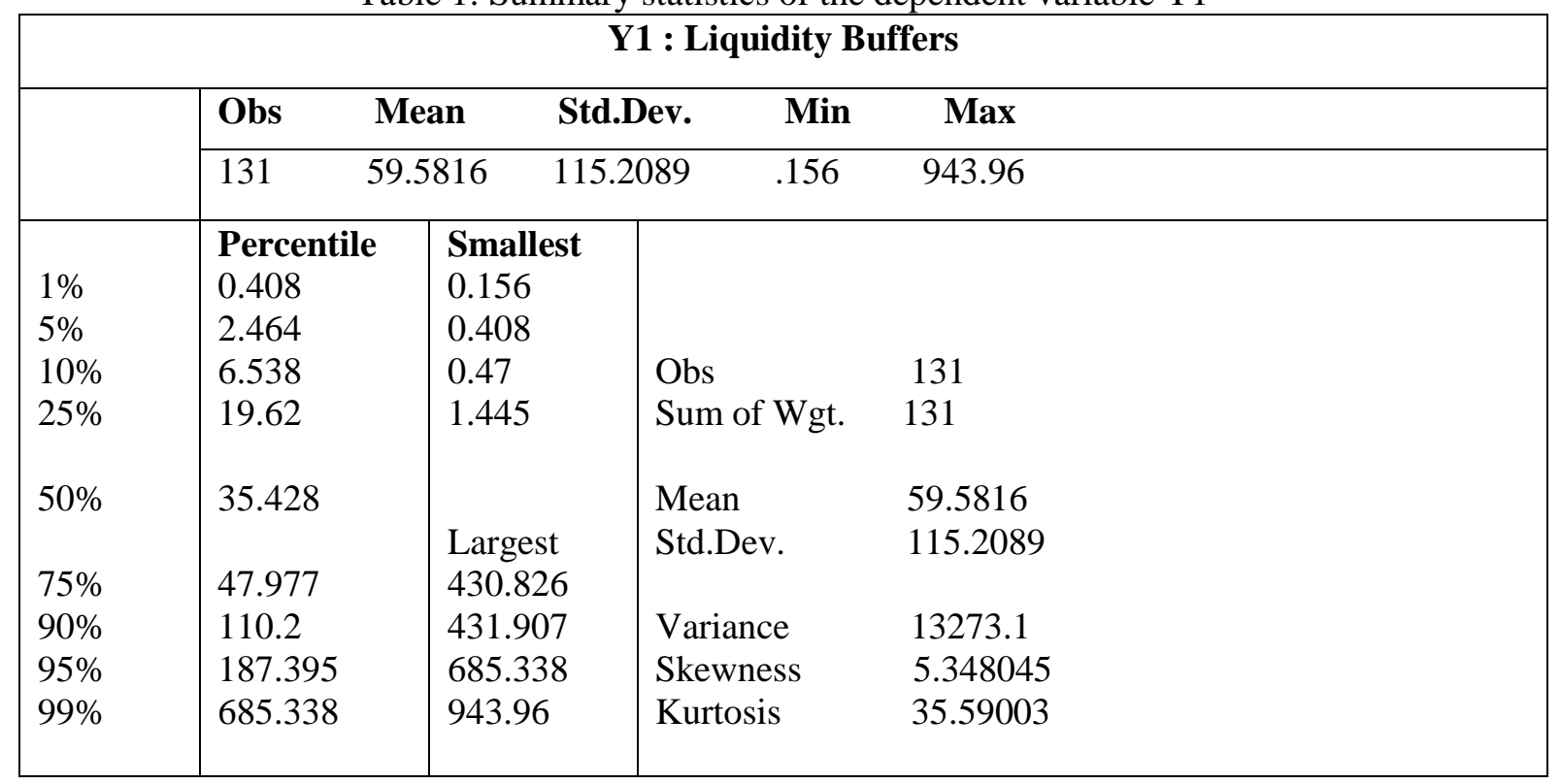

Liquidity buffer has an average value of 59.58 and a very high stander deviation of 115.20 that contradicts with the most common idea about Islamic banks, which is storing liquidity. This result shows an opposite fact to the standard idea; liquidity is not stable in Islamic banks hence it is constantly used. In addition, the very high stander deviation is explained by the unequal distribution of liquid assets among Islamic banks in our sample. In fact we can see that the bank which is keeping the highest level of liquidity buffer have around 944 million \$ of liquid asset however the bank with the lowest level of liquidity have only 0.156 million $\$$ of liquid assets. The same explanation is obtained from percentiles interpretation, comparing the first and last percentiles. An additional matter is noticed in this summary which is the value of the kurtosis that exceed 3 reaching 35.59 indicating that our dependent variable is not normally distributed which is basically due to the excess of volatility.

The Table 2 shows the summary statistics of the variables used in the model based on two main indicators, the bank idiosyncratic factors and economic cycles. 
Table 2: Summary statistics of the independent variables

\begin{tabular}{|l|lllll|}
\hline Variables & Obs & Mean & Std.Dev. & Min & MaX \\
\hline Bank & 184 & 12 & 6.651349 & 1 & 23 \\
Year & 184 & 2007.5 & 2.29754 & 2004 & 2011 \\
Y1 & 131 & 59.5816 & 115.2089 & 0.156 & 943.96 \\
X1 & 137 & 8846161 & $1.33^{\mathrm{e}}+07$ & 109000 & $5.94^{\mathrm{e}}+07$ \\
$\mathbf{X 2}$ & 145 & 26.9298 & 25.0455 & 3.573 & 98.93 \\
\hline $\mathbf{X 3}$ & 98 & 3.433582 & 3.141025 & 0 & 15.843 \\
$\mathbf{X 4}$ & 119 & 83.12263 & 211.5272 & 0.7523716 & 2135.979 \\
$\mathbf{X 5}$ & 135 & 2.806926 & 2.172463 & 5.407 & 10.419 \\
$\mathbf{X 6}$ & 131 & 52.485 & 19.93424 & 0 & 89.592 \\
$\mathbf{X 7}$ & 136 & 2.126213 & 4.447946 & -26.065 & 15.797 \\
\hline $\mathbf{Z 1}$ & 184 & 6.103133 & 5.011055 & -7.076103 & 26.17025 \\
$\mathbf{Z 2}$ & 184 & 9.160949 & 10.3083 & -24.2181 & 30.5427 \\
$\mathbf{Z 3}$ & 63 & 20.90895 & 10.63051 & 7.292633 & 35.9361 \\
\hline & 112 & 0.3675204 & 11.03233 & -18.30132 & 41.25295 \\
\hline
\end{tabular}

Y1: Liquidity buffers; X1: Total assets of the bank; L_x1: Log of total assets, which gives us the size of the bank; X2: Capitalization; X4: Deposit ratio; X6: Net loans over total assets; X7: Profitability; Z1: Real growth GDP; Z2: Inflation rate; Z3: Budget deficit; Z4: Real interest rate.

Looking to Table 2 we notice that deposit ratio $(\mathrm{x} 4)$ represents the highest mean value among the data 83.12, followed by capitalization (x2) 26.92, then net loans over total assets (x6) 52.48. However, variables like loan loss reserves (x3), and profitability(x7) showed respectively low means 3.42, 2.12. In addition, capitalization, deposit ratio and net loans over total assets represent the highest standard deviation values due to the high volatility caused by the high dispersion of the data. For instance, the standard deviation of deposits is 211.52 with the lowest level of deposits(x4) is $0.752 \mathrm{M} \$$ however the highest is $2135.97 \mathrm{M} \$$, while the mean value is 26.92 .

Besides, the size variable has relatively a low standard deviation 1.59 and has a mean value of 14.90.Concerning macroeconomic and financial development variables we have the following figures: the government debt or deficit (z3) represents the highest mean 20.90 while real interest rate (z4) represents the lower mean among the control variables with a mean value of 0.36 . However, the same variable have the highest stander deviation 11.03 while real GDP growth (z1) have the lowest volatility 5.011. 
Correlation analysis is a simple test to detect the existence of collinearity in a multi-variable regression, based on the variable's correlation matrix. Table 3 indicates that dependent variables like performance (x7) and net loans over total assets (x6) and deposits have a very week correlation between them (significant at 1\%), so it is not going to harm our estimation. However, it is noticed that all dependent variables are correlated to real interest rate (z4) which may cause a multicollinearity problem that will affect the regression. This issue is checked in the next section using a post estimation multicollinearity test

Table 3: Correlation statistics of the variables

\begin{tabular}{|c|c|c|c|c|c|c|c|c|c|}
\hline & L_X1 & $\mathrm{X} 2$ & $\mathrm{X} 4$ & X6 & $\mathrm{X} 7$ & $\mathrm{Z1}$ & $\mathrm{Z2}$ & $\mathbf{Z 3}$ & $\mathbf{Z 4}$ \\
\hline L_X1 & 1.0000 & & & & & & & & \\
\hline$\overline{\mathrm{X} 2}$ & -0.6239 & 1.0000 & & & & & & & \\
\hline $\mathrm{X4}$ & -0.2053 & -0.0700 & 1.0000 & & & & & & \\
\hline X6 & 0.2936 & -0.2640 & -0.0918 & 1.0000 & & & & & \\
\hline $\mathrm{X} 7$ & -0.1155 & 0.2552 & 0.0722 & -0.0534 & 1.0000 & & & & \\
\hline $\mathbf{Z 1}$ & -0.1197 & 0.0386 & -0.0561 & 0.0707 & 0.2057 & 1.0000 & & & \\
\hline $\mathbf{Z 2}$ & 0.1126 & -0.1187 & -0.1571 & 0.0374 & -0.0730 & 0.3678 & 1.0000 & & \\
\hline $\mathbf{Z 3}$ & 0.2418 & -0.1262 & -0.1368 & 0.1395 & -0.4889 & -0.5176 & 0.1784 & 1.0000 & \\
\hline $\mathbf{Z 4}$ & -0.0071 & 0.0505 & -0.0671 & 0.0373 & 0.0965 & -0.3372 & -0.9548 & -0.2273 & 1.0000 \\
\hline
\end{tabular}

\subsection{Model specification}

In this section, we use the model of Bonner et al. (2015) which is the latest recent paper in this matter. Furthermore, the model provides clearer information and fits our dataset.

The base line model from Bonner et al. (2015) is used with some modifications. For instance, deposit insurance is eliminated because it does not exist in our data's sample. In addition, we eliminate the business model dummy variables as from the beginning we chose only commercial Islamic banks for the study; hence this dummy is irrelevant in our case. Furthermore, we chose different proxies for profitability due to data availability. Finally, we added net loans over total assets, as a proxy for bank's risk appetite as a fifth idiosyncratic factor that was not included in the initial model by Bonner et al. (2015).

The baseline specification is represented by the following equation:

$$
\text { liquidity }_{i, t}=\alpha+\beta_{i, t} \text { bank }_{i, t}+\beta_{i, t} \text { macro }_{i, t}+\varepsilon_{i, t}
$$

Where liquidity $_{i, t}$ measures liquidity holdings in Islamic banks i during time t.bank $k_{i, t}$ Is a set of i bank and t time-varying factor, which includes, bank's size (total assets), profitability (ROAA), capitalization (bank's capital over total assets), the share of its total deposits in total assets as well as the share of its loan in the total assets. macro $_{i, t}$, control for $\mathrm{i}$ bank and time varying aspects of macroeconomic condition. Finally, $\varepsilon_{i, t}$ is an i bank clustered error term which allow us to estimate our model with OLS ( at first) without being exposed to some shortcomings like omitted variables, misspecification of the model, or any other estimation errors that cannot be captured by our model. 


\subsection{Estimation methodology}

We first run an OLS regression using the main variables $(\log (x 1), x 2, x 4 x 6, z 1$ z2 z3 z4) then we run a set of post estimation tests.

We start by running autocorrelation test, we find out that the mean VIF exceed 6 which indicates an autocorrelation problem, as shown on the section 1 of Table 4.

Table 4: Autocorrelation Test

\begin{tabular}{|c|c|c|c|c|c|}
\hline \multirow[t]{2}{*}{ Variable } & \multicolumn{2}{|c|}{ First autocorrelation test } & \multicolumn{3}{|c|}{ Second auto correlation test } \\
\hline & VIF & 1/VIF & Variable & VIF & 1/VIF \\
\hline $\mathbf{Z 4}$ & 1168.48 & 0.000856 & $\mathrm{Z} 1$ & 8.16 & 0.122568 \\
\hline $\mathbf{Z 2}$ & 1129.05 & 0.000886 & $\mathrm{Z3}$ & 6.72 & 0.148825 \\
\hline $\mathbf{Z 3}$ & 6.88 & 0.145297 & $\mathrm{X} 2$ & 4.29 & 0.233084 \\
\hline $\mathbf{Z 1}$ & 5.44 & 0.183806 & L_x1 & 4.21 & 0.237400 \\
\hline $\mathbf{X} 2$ & 3.97 & 0.252069 & $\mathrm{Z} 2$ & 3.03 & 0.330216 \\
\hline L_X1 & 3.80 & 0.263138 & $\mathrm{X} 7$ & 2.31 & 0.433448 \\
\hline $\mathbf{X} 7$ & 2.14 & 0.467080 & L_z4 & 1.89 & 0.529165 \\
\hline X6 & 1.71 & 0.584011 & X6 & 1.75 & 0.571501 \\
\hline $\mathbf{X} 4$ & 1.27 & 0.788034 & $\mathrm{X} 4$ & 1.35 & 0.739807 \\
\hline Mean VIF & \multicolumn{2}{|c|}{258.08} & \multicolumn{3}{|c|}{3.75} \\
\hline
\end{tabular}

We then checked the individual VIF to find out that this indicator exceed 10 for the government deficit $(\mathrm{z} 3)$ and the real interest rate $(\mathrm{z} 4)$. We transform the real interest rate $(\mathrm{z} 4)$ to its lag (lz4). Than we rerun the regression followed by the same test, as shown in Table 4.

This time all the individual VIFs are less than 10 and the mean VIF was less than 10 (it was 3.75). Therefore, the autocorrelation problem is solved. After that, we run a heteroskedasdisity test. We find that the p-value of the test was less than 5\%, thus we cannot accept H0, which is the constant variance. Hence, the breuch-pagan/ cook-weisberg test indicates the existence of heteroskedasticity.

To fix this problem we estimate our model using the generalized least square GLS. The GLS is globally significant with a variation in the individual significance of each variable.

In addition, as we are using panel data, and to be sure of our results, we choose to run the Hausman specification test. Therefore, we run a fixed effect regression then a random effect one and we finish by running the Hausman test. Table 5 presents all results. 
Table 5: Main estimations results

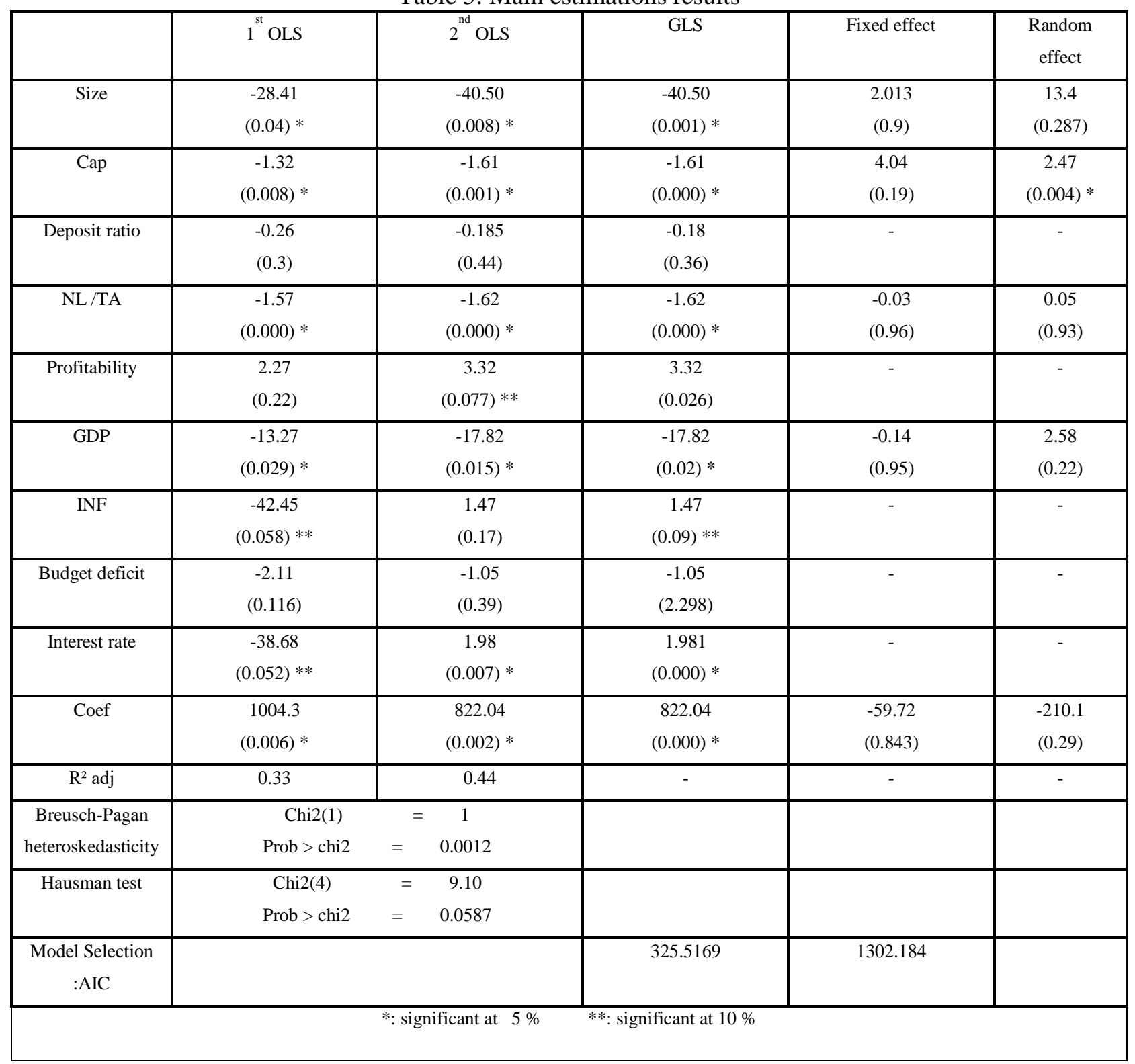

Results show that the fixed effect is the right one to choose. This result is consolidated by the fact that we found the fisher statistic on the fixed effect regression 0.000 least than $5 \%$, which indicates the absence of homogeneity in our panel data set, hence the best model to fit in this case is the fixed effect model. Since we run different regression, we use the awake information criterion AIC to choose between them. According to this test, the regression that has the smallest AIC is the best.

Results of the test reveal that the GLS is the best model in this case. Therefore, interpretation is based on the coefficient estimated by the GLS. Finally, we run the endogeneity tests and we find that all our variables are exogenous (Table 6). 
Tables 6: Endogeneity tests

\begin{tabular}{|l|l|l|l|l|}
\hline Variables & $\mathrm{X} 2$ & $\mathrm{X} 4$ & $\mathrm{X} 6$ & $\mathrm{X} 7$ \\
\hline $\begin{array}{l}\text { Durbin (score) } \\
\text { chi2 (1) }\end{array}$ & 0.02 & 1.03 & 0.005 & 0.03 \\
\hline p-value & 0.8726 & 0.3088 & 0.9389 & 0.85409 \\
\hline
\end{tabular}

\section{The main results}

As regard to this sub-sample, results are statistically significant (see Table 5) and support a number of predictions outlined in the literature section.

First, as shown in Table 6, the position of liquid assets is negatively related to the size of the bank (significant with a p-value $=0.001$ ). This confirms the prediction we have developed in the theoretical section about "too big to fail". This is also in line with the result of Ahmad et al. (2013), indicating that even if Islamic banks have religious incentive to keep higher liquidity so they have a minimum risk, Islamic banks behave just like their conventional peer even if they do not enjoy the same option like the lender of last resort and the deposit insurance. Actually, this is not the only explanation of this result, this output could be explained by another reason founded in the literature which is the support of the financial authorities and government bailouts (Kim and Sohn, 2017). This indicates the existence of discrete governmental bailouts in the GCC countries to support large Islamic banks in the region.

Second, we found that capitalization is negatively related to liquidity buffers in Islamic banks in the GCC region (with a p-value $=0.000$ ). In fact, when capitalization increases liquidity buffer is reduced by $162 \%$. This result is in line with the findings of Ahmad et al. (2013) and Ashraf et al. (2016). Despite the fact that this result is in line with our prediction it is controversial from the conventional litterature's perspective. This result is supposed to be negative because better-capitalized banks have an easier access to financial markets, which explains their tendency to have less liquidity buffers. However, in the case of Islamic banks the access to financial markets is limited regarding the lack of Sharia compliant liquidity management instruments. This lack is in terms of both quality and quantity. Hence, this result indicates that Islamic banks in the GCC countries are using interest bearing financial instrument to raise funds, which is the case in both Kuwait and Saudi Arabia since they have a weak financial regulation when it comes to Islamic securities issuance comparing to the rest of gulf country. This fact may affect the results of our sub-sample.

Third, the ratio of deposits is negatively related to liquid assets holding in Islamic banks however it is statistically not significant (with a p-value $=0.366$ ). This is not what we expect in our predictions. Although the coefficient is not significant, it shows a negative sign which can be explained by the fact that lower oil processing activities had reduced the flow of deposits from governments and government related entities in the GCC countries. We can argue also that since the GCC region is a union, this unity might provide a more stable environment for business facilities and investment decision making. Besides, it can reduce transaction costs (Srairi, 2010). Intuitively one's can argue that banks may be dealing with each other's based on over the counter operations like commodity murabaha, which is an Islamic forward contract (Ali, 2013). Alternatively, just a transfer operation in which one bank will be the trustee of the other through Wakala contract.

Forth, the risk appetite for Islamic banks is negatively related to liquidity buffer in Islamic banks in the GCC region (with a p-value $=0.000$ ). In fact, when the share of loans in bank total assets increases, liquidity buffers decreases by $162 \%$. It has almost the same effect of capitalization on Islamic banks liquidity holdings. This result is in line with the literature and our prediction. However, it contradicts with 
the hypothesis established on the base of Islamic banks characteristics; which is the religious incentives dictating a lower level of risk taking (Adhikari and Agrawal, 2016) and thus a higher liquidity positions.

Fifth, we find a positive relationship between the profitability and liquid assets holding in Islamic banks of the GCC region (with a p-value $=0.026$ ). In fact when profitability increases, liquid assets holding increases by $332 \%$. This confirms our prediction. This is in line with what the literature says (Molyneux and Thornton, 1992; Shahchera, 2012; and Ahmad et al., 2013). Most importantly, this is in line with what Ahmad et al. (2013) state in their research, that Islamic banks' profits are procyclical, therefore better profitability will allow better liquidity levels.

Finally, we find a different result when it comes to macroeconomic variables. These results are not all in line with our prediction. We find a negative impact of the inflation on liquidity buffers which is in line with the literature (Ahmad et al, 2013; Bonner et al. 2015; and Aspachs et al. 2005). In addition, we find a positive significant impact of GDP real growth and liquidity buffers in Islamic banks in the GCC region. This is in line with the findings of Ahmad et al. (2013). They argue that better economic conditions improve business prospects for Islamic banks. Hence, liquidity will be improved. However, this contradicts with what Aspachs et al. (2005) and Almeida et al. (2004) state about the fact that banks tend to have less liquidity during economic growth because they are hoarding liquidity to when economic conditions are weak. Moving on to the government deficit we did not find a significant relationship between this variable and liquidity buffers, which contradicts with our prediction. Finally, we find a positive relationship between real interest rate and liquidity buffers which is not in line with the literature.

\section{Conclusion}

The object of this paper is to understand the determinants of liquidity buffers in the CCG countries. Results are statistically significant and support a number of predictions outlined in the literature section. First, the position of liquid assets negatively related to the size of the bank. The capitalization is negatively related to liquidity buffers in Islamic banks in the GCC region. In fact, when capitalization increases liquidity buffer is reduced by $162 \%$. This result is in line with the findings of Ahmad et al. (2013) and Ashraf et al. (2016).

The ratio of deposits is negatively related to liquid assets holding in Islamic banks; however, it is statistically not significant. This can be explained by the fact that lower oil processing activity had reduces the flow of deposits from governments and government related entities in the GCC countries. The risk appetite for Islamic banks is negatively related to liquidity buffer in Islamic banks in the GCC region. In addition, we found a positive relationship between the profitability and liquid assets holding in Islamic banks of the GCC region. In fact when profitability increases, liquid assets holding increases by $332 \%$. This is in line with Ahmad et al. (2013) who state in their research, that Islamic banks' profits are procyclical, therefore better profitability will allow better liquidity levels.

Finally, we found a different result when it comes to macroeconomic variables. First, a negative impact of the inflation on liquidity buffers. Second, a positive significant relation between GDP real growth and liquidity buffers in Islamic banks in the GCC region. This is in line with the findings of Ahmad et al. (2013).

As it was shown by Ahmad et al. (2013), our results indicate that even if Islamic banks have religious incentive to keep higher liquidity so they have a minimum risk, Islamic banks behave just like their conventional peer even if they do not enjoy the same option like the lender of last resort and the deposit insurance.

The findings of this study are relevant and valuable to both Islamic banks and policy makers and give a new insight about the dynamic of liquid assets in Islamic banks. The results are important because they provide a tool to future liquidity management applications. 
For future studies, detailed investigations about liquidity buffers are required. For instance, investigating the impact of share of investment accounts over deposit - which reflects the profit loss principle-, provides a constructive insight for both banks and authorities. Furthermore, as the sharia board differs in structure from one bank to another, checking the sharia board structure's impact is crucially important. For instance in the GCC countries each bank has its own sharia board (Abdul-Rahman, 2010). Hence, sharia board's decisions are not standardized which means each bank has its proper strategy when it comes to liquidity position. This means that some Islamic banks driven by a strong religious incentive of the board are forced to keep a large liquidity buffer pool, to prevent high-risk levels. Yet, in other banks, having a board considered as more flexible might issue a flexible "Fatwa" allowing the use of certain liquidity instruments. Besides, investigating the impact of regulation on liquidity buffers is very important, because Islamic banks operate in different countries with different legal backgrounds. Finally, future researches should focus more on the comparison between GCC and South East Asia region because such studies open ways for collaboration between both regions that will ensure a better future for Islamic banks in both regions.

\section{References}

Abdul-Rahman, Y. (1999) Islamic instruments for liquidity management. International Journal of Islamic Financial Services, 1(1), 34-46.

Adhikari, B.K. \& Agrawal, A. (2016) Does local religiosity matter for bank risk-taking. Journal of Corporate Finance, 38(2), 272-293.

Ahmad, A.Z. Mhammed, M. T. and Samsudin, M.L. (2013) How Islamic banks of Malaysia managing liquidity? An emphasis on confronting economic cycles. International Journal of Business and Social Science, 4(7), 254-262.

Ali, S.S. (2013) State of liquidity management in Islamic financial institution. Islamic Economic Studies, 21(1), 63-98.

Almeida, H., Campello, M. and Weisbach, M.S. (2004) The cash flow sensitivity of cash. The journal of finance, 59(4), 1777-1804.

Ashref, D., Rizwan, M.S. and L'huilier, B. (2016) A net stable funding ratio for Islamic banks and its impact on financial stability: an international investigation. Journal of Financial Stability, 25, 4757.

Aspachs, O., Nier, E. and Tiesset, M. (2005) Liquidity, banking regulation and the macroeconomy: Evidence on Bank Liquidity holdings from a Panel of UK-Resident Banks. Mimeo, 1-26.

Bonner, C., Lelyveld, I. and Zymek, R. (2015) Banks' Liquidity Buffers and the Role of Liquidity Regulation. Journal of Financial Services Research, 48(3), 215-234.

Čihák, M. and Hesse, H. (2010) Islamic banks and financial stability: An empirical analysis. Journal of Financial Services Research, 38(2), 95-113.

Delechat, C., Henao, C., Mthoora, P.M and Vtyurina, S. (2012) The determinants of bank's liquidity buffers in Central America, working paper, IMF.

Hassan, M. and Dridi, D. (2010) The effect of the global crisis on Islamic and conventional banks: a comparative study. working paper. IMF.

How, J.C., Abdul Karim, M. and Verhoeven, P. (2004) Islamic financing and bank risk, Tunderbird International Business Review, 47(1), 75-94.

Iqbal, Z. and Mirakhor, A. (2007) An Introduction to Islamic Finance: Theory and Practice. John Wiley and Sons, Asia.

Molyneux, P. and Thornton, J. (1992) Determinants of European bank profitability: a note. Journal of Banking and Finance, 16(6), 1173-1778.

Ismal, R. (2008) Shariah issues in liquidity risk management: A survey. Review of Islamic Economics, 12(2), 45-66. 
Ismal, R. (2010) Assessment of liquidity management in Islamic banking industry. International Journal of Islamic and Middle Eastern Finance and Management, 3(2), 147-167.

Shahchera, M. (2012) The impact of the liquidity if Iranian bank on profitability. Money and Economy, $7(1), 140-160$.

Srairi, S.A. (2010) Cost of efficiency of conventional and Islamic banks in GCC countries. Journal of Productive Analysis, 34(1), 45-62.

Vogel, F. and Hayes, S. (1998) Islamic law and finance: religion, risk and return. Kluwer Law International, London. 